
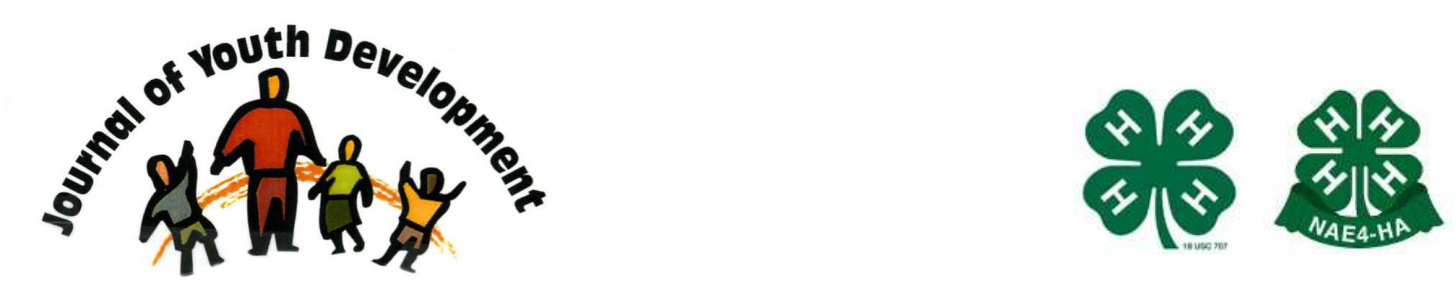

Bridging Research \& Practice

\title{
Trends in Youth Development Research Topics: An Integrative Review of Positive Youth Development Research Published in Selected Journals Between 2001-2010
}

\author{
Robert J. Barcelona \\ Clemson University \\ rbj@clemson.edu
}

William Quinn

Clemson University 


\title{
JOURNAL OF YOUTH DEVELOPMENT \\ bridging research and practice

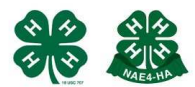

Bridging Research \& Practice

Volume 6, Number 3, Fall 2011

Article 110603FA002

\section{Trends in Youth Development Research Topics: An Integrative Review of Positive Youth Development Research Published in Selected Journals Between 2001-2010}

Robert J. Barcelona and William Quinn

Clemson University

\begin{abstract}
The body of knowledge related to positive youth development has grown in the last two decades, yet there have been few, if any, systematic investigations of the research base in the field. Therefore, the purpose of this paper was to identify the trends in research topics and approaches within the field of positive youth development over the last 10 years by examining five top-tier research journals plus one research-to-practice journal. Results revealed that only $19 \%$ of the manuscripts published in all of the selected journals had a positive youth development focus, and this was reduced to $13 \%$ when just the five top-tier research journals were considered. Analyses of the positive youth development manuscripts pertaining to population characteristics, methodology, research setting, and topical areas provide a snapshot of the trends and gaps in the body of knowledge related to youth development, and have implications for future research efforts in the field.
\end{abstract}

\section{Introduction}

Over the past 20 years, the field of youth development has witnessed a shift in practice from single issue programs that address specific problem behaviors to more comprehensive strategies that provide broad supports for all youth focusing on their needs and competencies. Prior to the 1990s, the basic idea was that positive development was defined by the absence of problem behavior (Benson, Scales, Hamilton, \& Sesma, 2006; Lerner, 2005). In the last 20 years, there has been a movement away from viewing youth as "problems to be managed" to one that views them as assets capable of influencing their own development (Roth, BrooksGunn, Murray, \& Foster, 1998). However, there have been few or no published studies that provide a systematic investigation of the body of knowledge that encompasses the field of 
positive youth development. This special issue of the Journal of Youth Development provides a golden opportunity to undertake this challenge.

One useful method for determining research trends within a particular discipline is to conduct an integrative review of the literature within the field. Integrative reviews are systematic analyses of the research literature, with the intention of more fully grasping the issues and topics addressed in the overall body of knowledge (Jackson, 1980). To date, there have been no known integrative reviews published that cover the broad discipline of positive youth development. While Bocarro, Greenwood, and Henderson (2008) conducted an integrative review of research related to youth development, they delimited their study to just those articles published in four recreation and leisure studies journals.

Therefore, the purpose of this paper was to examine the trends in research topics and approaches within the field of positive youth development, by focusing on four key areas: population characteristics, methodology, research setting, and topical areas covered. This exploration will allow scholars and practitioners to make generalizations about the youth development research, and assess the overall body of knowledge relative to what needs to be known about the field. Researchers can also identify gaps in topic areas and methods that can ultimately provide an agenda for future research directions.

\section{Literature Review}

Integrative reviews have been conducted on numerous topics related to youth in the past ten years. For example, such approaches have been used to understand the experiences of immigrant and ethnic minority children (Guiberson, 2009; Stodolska, 2008; Telzer, 2011), adolescent peer experiences (Kingery, Erdley, Marshall, Whitaker, \& Reuter, 2010), emotional regulation (Chambers, Gullone, \& Allen, 2009), sports coaching (McCullick et al., 2009), and family resiliency (Benzies \& Mychasiuk, 2009). Integrative reviews have been undertaken to understand trends in topical content and methods, such as Graham and Ismail's (2011) study conducted in the field of community psychology. Of particular interest to this study is Bocarro, Greenwood, and Henderson's (2008) integrative review on youth development and recreation.

While the disciplines vary in the papers mentioned above, all attempt to provide some guidance to research investigators regarding the direction of the accumulation of knowledge. Because journal articles are indicators of the patterns of thinking that help to define specific fields, it makes sense that scholars and practitioners would be interested in the aggregated body of knowledge that helps to define a particular disciplinary domain (Graham \& Ismail, 2011). As the field of youth development has matured, a case can be made that it is time to look more systematically at the research efforts in the field. By doing so, researchers and practitioners can utilize the knowledge base to inform key stakeholders in a manner that optimally contributes to youth well-being.

\section{Background and Approach}

One of the methodological challenges in identifying trends in youth development research is reasonably identifying what constitutes "youth development" research. There is a long and rich history of research in adolescent development that focuses on cognitive, physical, social, and emotional maturational processes (Lerner, 2005; Pittman \& Wright, 1991). While this body of knowledge is a useful platform to frame an understanding of adolescent development, the term youth development is generally understood to be the application of this knowledge to intentional strategies for promoting positive youth well-being. 
Youth development encompasses a specific set of principles and practices that help to mold and shape the developmental process. These principles generally include a focus on the assets and strengths of young people, as opposed to a focus on understanding problems or deficits (Roth \& Brooks-Gunn, 2003). Youth development principles also focus on supportive adult relationships, healthy and stimulating environments conducive to learning and skill attainment, formation and availability of challenging programs and activities, and recognition of the important role that youth themselves play in the process of their own well-being (Hamilton, Hamilton, \& Pittman, 2004; Pittman \& Wright, 1991). Youth development is put into practice within contexts and settings that are safe, appropriately structured, foster supportive relationships, provide opportunities to belong, model positive social norms, support efficacy and mattering, provide opportunities to build skills, and provide a dynamic flow among various ecological systems (i.e. family, school, community) (Eccles \& Gootman, 2002). In sum, youth development is both theoretical and applied, particularly within community-based programs and organizations.

For the purposes of this review, it was important to be able to distinguish between "research on youth" and "youth development research." Based on the general principles and practices of youth development explained above, we attempted to focus on studies that

1) were youth-focused;

2) selected variables that addressed relationships, supports, opportunities, programs, or services that were intentionally designed to influence positive well-being;

3) focused on strengths and assets as opposed to studies addressing specific problems or deficits; and

4) explored the profession of youth development, including studies on training, staffing, and leadership.

To establish the boundaries for this review and to capture the academic discipline of youth development, we did not include studies that were primarily focused on general adolescent development or maturational processes, or those studies that were focused primarily on particular problem behaviors (e.g. binge drinking, depression, eating disorders, suicide).

One of the other methodological challenges with a youth development research review is to define an age span that comprises the term "youth." Most scholars have noted that the term "youth" encompasses approximately the second decade of life, corresponding to between 10 and 20 years of age (Hamilton, Hamilton, \& Pittman, 2004; Lerner 2005). However, there is growing support for the notion that the definition of youth is extending in both directions. For example, Larson (2002) discusses the idea of a raised bar for adulthood in the twenty-first century, particularly as a result of increasing educational demands and employment constraints placed on adolescents. Others have noted the increasing occurrence of early pubertal development, particularly for girls (Steingraber, 2007), and the increasing cognitive capacities of young people as a result of their access to information (Costello, Toles, Spielberger, \& Wynn, 2001). As such, it makes sense that youth development research could apply to those younger than ten and up to 25 years of age. To capture this, we included studies with children as young as 8 , and included studies on young adults through age 25 .

Finally, a decision had to be made regarding the publication years to include in the analysis. While youth development research has historical roots in developmental science that stretches back to the contributions of G. Stanley Hall (1904), much of what was published prior to the 
early 1990s focused on the absence of deficits or problem behaviors (Lerner, 2005; Pittman, Irby, \& Ferber, 2001; Roth \& Brooks-Gunn, 2003). Although researchers, practitioners, and policy makers were talking about positive youth development prior to the early $1990 \mathrm{~s}$, most point to Pittman and Wright's (1991) paper, Bridging the Gap: A Rationale for the Role of Community Organizations in Promoting Youth Development as being critical in shifting the focus from thinking of youth as "problems to be managed" (Roth, Brooks-Gunn, Murray, \& Foster, 1998) to one that views them as assets capable of influencing their own positive development (Costello et al., 2001). However, a decade after Pittman \& Wright's (1991) seminal paper, some scholars contended that there was still a lack of research and theory in positive youth development (Larson, 2000), while others were still trying to define the characteristics of a positive youth development program (Roth \& Brooks-Gunn, 2003).

Thus it made sense, both from a practical and theoretical perspective, to examine the trends in positive youth development research over the past 10 years (from 2001 to 2010). Precedence has been set with various disciplines conducting decade reviews. For example, decade reviews have been conducted on the research literature in related disciplines such as family studies (Bogenschneider \& Corebett, 2010; Kosutic \& McDowell, 2008; D'Onofrio \& Lahey, 2010), and healthcare (Chesla \& Rungreangkulkij, 2001). In addition, the Journal of Research on Adolescence has recently published a special issue featuring a series of decade reviews covering a range of youth-related topics (Russell, Card, \& Susman, 2011).

\section{Methodology}

While many scholarly journals publish research articles that pertain to children and adolescents, only a few focus solely on this population. For this study, we selected journals that had the words "youth" and/or "adolescent" in their title because such a strategy allowed us to capture a large body of research that would pertain to the field of youth development. To better understand the nature and extent of positive youth development research since 2001, we identified six journals that fit the criterion for review - Journal of Research on Adolescence (JRA), Journal of Adolescence (JA), Journal of Adolescent Research (JAR), Youth \& Society (Y\&S), Journal of Youth and Adolescence (JYA), and Journal of Youth Development (JYD). The first five journals were chosen because they are widely accepted as top-tier scholarly journals that focus on publishing work specifically related to youth and adolescence. The Journal of Youth Development was included because it has a primary role as an outlet for disseminating youth development research, and because it provides practitioner-focused research on youth development programs and contexts.

It is well understood that research about youth is published in a wide-variety of journals covering a range of professions that serve youth. For example, youth-oriented research is typically published in noted journals such as Developmental Psychology, Journal of Community Psychology, Applied Developmental Science, Child Development, and the Journal of Applied Developmental Psychology. Research on youth development has also appeared in journals specific to fields such as social work (e.g. Social Work Review), family studies (e.g. Journal of Marriage and Family), outdoor education (e.g. Journal of Experiential Education), health (e.g. Journal of Adolescent Health), and leisure studies (e.g. Journal of Park and Recreation Administration). While important contributions to youth development have been found in these journals, we delimited our analysis to only those journals that focus entirely on youth-related topics and that publish research from a broad array of professional settings and disciplinary topics (i.e. that are not focused on a particular aspect of youth development, such as health or recreation). 


\section{Procedures}

Both of the authors and two trained graduate students in Clemson University's Youth Development Leadership Program each were assigned journals to scan for evidence that published articles met the criteria for inclusion in the study. Titles that clearly met the general principles and practices of youth development were retained. For example, words or terms such as well-being, adjustment, leadership, career planning, health, support, sports participation, and academic success led to inclusion. Titles that were clearly outside the scope of the project (i.e. those that were focused on general developmental processes or had a primary focus on deficits or problem behavior) were excluded.

The research team met to review the titles of all selected articles within the 2001-2010 time frame. The final list of manuscripts retained for analysis was determined following a discussion by the team and by consensus agreement. In a few cases no clear decision could be reached. This was usually because titles were ambiguous in that they included words that reflected positive youth well-being as well as terms that connoted adolescent developmental processes or problem-behaviors. In these cases, the research team collectively reviewed the abstract to determine whether to include the manuscript for analysis.

Following selection of the sample of articles to be included, the research team reviewed their assigned articles and categorized key pieces of information describing the study. Both deductive and inductive coding schemas were used in the process of categorizing articles (Graham \& Ismail, 2011). For example, deductive coding was used to categorize publication type, methodologies employed, and population characteristics. Inductive coding was used to identify key topical areas and themes. For example, each member of the research team identified three to five key words that captured the general topical areas covered in their assigned articles. The team combined their list of key words, removed redundancies, and met to discuss common topical areas that emerged from their individual analyses. From this, a list of 23 topical areas was developed. These 23 topical areas were further refined and collapsed into 12 dominant themes found in the manuscripts that were reviewed. The research team then categorized their assigned manuscripts based on the topical area/s that best represented the research. A nonexclusive categorization system was used to capture the breadth and scope of the research focus, so manuscripts were often placed into more than one topical area (Bocarro, Greenwood, \& Henderson, 2008; Graham \& Ismail, 2011).

\section{Data Analysis}

Figure 1 shows the breakdown of manuscripts retained for analysis by journal title as a percentage of all of the manuscripts published in the selected journals between 2001-2010. The results of this effort yielded the following: Journal of Research on Adolescence (26 out of 284, 9\%), Journal of Adolescence (50 out of 659, 8\%), Journal of Adolescent Research (37 out of $317,12 \%)$, Youth \& Society (73 out of 216, 34\%), Journal of Youth and Adolescence (99 out of $760,13 \%$ ), and Journal of Youth Development (all research manuscripts $=177$ ). Thus, the percentage of research manuscripts categorized for this study as positive youth development research was 462/2413 (19\%). Eliminating the Journal of Youth Development reduced this number further to $285 / 2236$ (13\%). 
Figure 1

Percentage of Manuscripts Published in Research Journals from 2001-2010

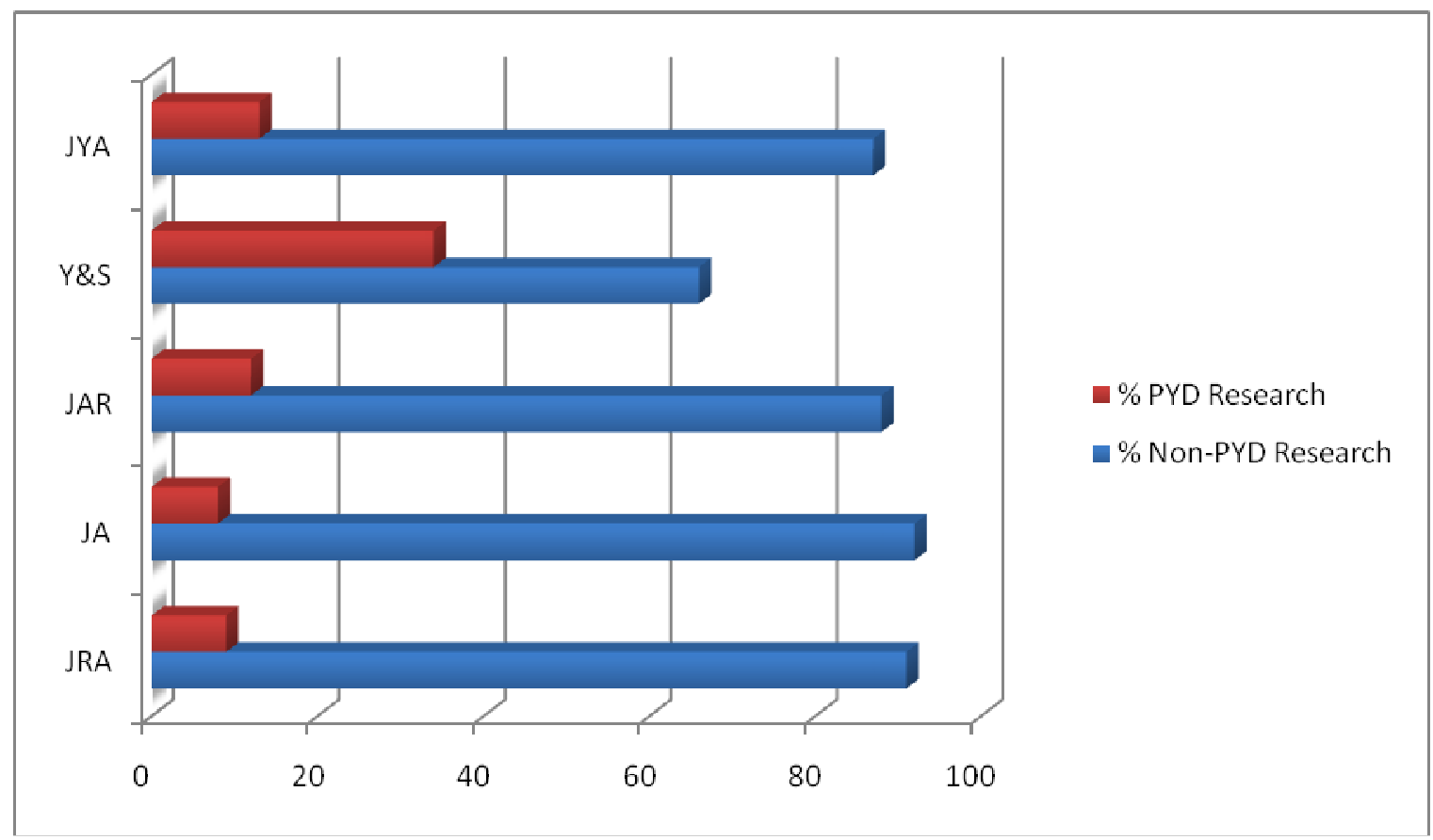

Note: JRA = Journal of Research on Adolescence, JA = Journal of Adolescence, JAR = Journal of Adolescent Research, Y\&S = Youth \& Society, JYA = Journal of Youth and Adolescence. The Journal of Youth Development was omitted here, as all 177 research articles were classified as having a PYD focus.

\section{Population Characteristics}

Table 1 includes the breakdowns of the population characteristics identified in this review. The majority of positive youth development articles published (65\%) dealt with early adolescence (ages 13-15), and roughly half (52\%) addressed late adolescence (ages 16-18). Approximately 1 in 5 articles (22\%) focused on the key adolescence transition years (ages 10-12), and only $16 \%$ addressed the traditional college-age population. Only $5 \%$ of published articles addressed ages associated with the transition to adulthood (ages 22-25).

With respect to sex and gender, there were few published manuscripts identified that focused exclusively on either boys or girls, although $5 \%$ of manuscripts were girls-only studies. Interestingly, we identified only one study published in the last ten years that was focused exclusively on boys within a positive youth development context. The vast majority of the manuscripts published included both boys and girls in their sample (87\%).

Approximately $8 \%$ of the studies did not include youth in their sample frame, but instead focused on key adult figures, such as parents, teachers, or youth serving professionals.

Manuscripts that included the perspectives of adults, either as the sole population studied or in addition to youth, accounted for a relatively small number of the published studies on positive youth development. For example, roughly $11 \%$ of studies included the perspectives of parents, and only $7 \%$ included teachers, adult program leaders or youth development professionals.

Only $3 \%$ focused on multiple adult stakeholders. 
Table 1

Population Characteristics

\begin{tabular}{|c|c|c|c|c|c|c|c|}
\hline & JRA & JA & JAR & JYD & Y\&S & JYA & Total \\
\hline \multicolumn{8}{|l|}{ Age } \\
\hline Under 10 & $\begin{array}{c}1 \\
(4 \%)\end{array}$ & $\begin{array}{c}1 \\
(2 \%)\end{array}$ & $\begin{array}{c}0 \\
(0 \%)\end{array}$ & $\begin{array}{c}7 \\
(4 \%)\end{array}$ & $\begin{array}{c}5 \\
(7 \%)\end{array}$ & $\begin{array}{c}9 \\
(9 \%)\end{array}$ & $\begin{array}{c}23 \\
(5 \%)\end{array}$ \\
\hline $10-12$ & $\begin{array}{c}5 \\
(19 \%)\end{array}$ & $\begin{array}{c}6 \\
(12 \%)\end{array}$ & $\begin{array}{c}4 \\
(12 \%)\end{array}$ & $\begin{array}{c}32 \\
(18 \%)\end{array}$ & $\begin{array}{c}15 \\
(21 \%)\end{array}$ & $\begin{array}{c}38 \\
(38 \%) \\
\end{array}$ & $\begin{array}{c}100 \\
(22 \%)\end{array}$ \\
\hline $13-15$ & $\begin{array}{c}13 \\
(50 \%)\end{array}$ & $\begin{array}{c}27 \\
(54 \%)\end{array}$ & $\begin{array}{c}23 \\
(62 \%)\end{array}$ & $\begin{array}{c}136 \\
(78 \%)\end{array}$ & $\begin{array}{c}48 \\
(66 \%)\end{array}$ & $\begin{array}{c}54 \\
(55 \%)\end{array}$ & $\begin{array}{c}301 \\
(65 \%) \\
\end{array}$ \\
\hline $16-18$ & $\begin{array}{c}16 \\
(62 \%)\end{array}$ & $\begin{array}{c}30 \\
(60 \%)\end{array}$ & $\begin{array}{c}27 \\
(73 \%)\end{array}$ & $\begin{array}{c}56 \\
(32 \%)\end{array}$ & $\begin{array}{c}51 \\
(70 \%)\end{array}$ & $\begin{array}{c}58 \\
(59 \%)\end{array}$ & $\begin{array}{c}238 \\
(52 \%)\end{array}$ \\
\hline $19-21$ & $\begin{array}{c}3 \\
(12 \%)\end{array}$ & $\begin{array}{c}8 \\
(16 \%)\end{array}$ & $\begin{array}{c}13 \\
(35 \%)\end{array}$ & $\begin{array}{c}11 \\
(6 \%)\end{array}$ & $\begin{array}{c}19 \\
(26 \%)\end{array}$ & $\begin{array}{c}19 \\
(19 \%)\end{array}$ & $\begin{array}{c}73 \\
(16 \%)\end{array}$ \\
\hline $22-25$ & $\begin{array}{c}0 \\
(0 \%)\end{array}$ & $\begin{array}{c}1 \\
(2 \%)\end{array}$ & $\begin{array}{c}2 \\
(5 \%)\end{array}$ & $\begin{array}{c}1 \\
(0 \%)\end{array}$ & $\begin{array}{c}11 \\
(15 \%)\end{array}$ & $\begin{array}{c}8 \\
(8 \%)\end{array}$ & $\begin{array}{c}23 \\
(5 \%)\end{array}$ \\
\hline \multicolumn{8}{|l|}{ Sex } \\
\hline Boys & $\begin{array}{c}0 \\
(0 \%)\end{array}$ & $\begin{array}{c}0 \\
(0 \%)\end{array}$ & $\begin{array}{c}0 \\
(0.0 \%)\end{array}$ & $\begin{array}{c}0 \\
(0 \%)\end{array}$ & $\begin{array}{c}0 \\
(0 \%)\end{array}$ & $\begin{array}{c}1 \\
(1 \%)\end{array}$ & $\begin{array}{c}1 \\
(0 \%)\end{array}$ \\
\hline Girls & $\begin{array}{c}2 \\
(8 \%)\end{array}$ & $\begin{array}{c}1 \\
(2 \%)\end{array}$ & $\begin{array}{c}1 \\
(3 \%)\end{array}$ & $\begin{array}{c}6 \\
(3 \%) \\
\end{array}$ & $\begin{array}{c}9 \\
(12 \%)\end{array}$ & $\begin{array}{c}3 \\
(3 \%) \\
\end{array}$ & $\begin{array}{c}22 \\
(5 \%) \\
\end{array}$ \\
\hline Both & $\begin{array}{c}23 \\
(89 \%)\end{array}$ & $\begin{array}{c}47 \\
(94 \%)\end{array}$ & $\begin{array}{c}35 \\
(95 \%)\end{array}$ & $\begin{array}{c}147 \\
(83 \%)\end{array}$ & $\begin{array}{c}56 \\
(77 \%)\end{array}$ & $\begin{array}{c}94 \\
(95 \%)\end{array}$ & $\begin{array}{c}402 \\
(87 \%)\end{array}$ \\
\hline \multicolumn{8}{|l|}{ Adults } \\
\hline Parents & $\begin{array}{c}1 \\
(4 \%)\end{array}$ & $\begin{array}{c}4 \\
(8 \%)\end{array}$ & $\begin{array}{c}4 \\
(11 \%)\end{array}$ & $\begin{array}{c}19 \\
(11 \%)\end{array}$ & $\begin{array}{c}8 \\
(11 \%)\end{array}$ & $\begin{array}{c}14 \\
(14 \%)\end{array}$ & $\begin{array}{c}50 \\
(11 \%)\end{array}$ \\
\hline Professionals & $\begin{array}{c}6 \\
(23 \%)\end{array}$ & $\begin{array}{c}0 \\
(0 \%)\end{array}$ & $\begin{array}{c}0 \\
(0 \%)\end{array}$ & $\begin{array}{c}18 \\
(10 \%)\end{array}$ & $\begin{array}{c}4 \\
(6 \%)\end{array}$ & $\begin{array}{c}4 \\
(4 \%)\end{array}$ & $\begin{array}{c}32 \\
(7 \%)\end{array}$ \\
\hline Other & $\begin{array}{c}0 \\
(0 \%)\end{array}$ & $\begin{array}{c}0 \\
(0 \%)\end{array}$ & $\begin{array}{c}0 \\
(0 \%)\end{array}$ & $\begin{array}{c}3 \\
(2 \%) \\
\end{array}$ & $\begin{array}{c}1 \\
(1 \%)\end{array}$ & $\begin{array}{c}1 \\
(1 \%)\end{array}$ & $\begin{array}{c}5 \\
(1 \%) \\
\end{array}$ \\
\hline Multiple & $\begin{array}{c}0 \\
(0 \%)\end{array}$ & $\begin{array}{c}1 \\
(2 \%)\end{array}$ & $\begin{array}{c}5 \\
(14 \%)\end{array}$ & $\begin{array}{c}3 \\
(2 \%)\end{array}$ & $\begin{array}{c}2 \\
(3 \%)\end{array}$ & $\begin{array}{c}3 \\
(3 \%)\end{array}$ & $\begin{array}{c}14 \\
(3 \%)\end{array}$ \\
\hline
\end{tabular}

Note: JRA = Journal of Research on Adolescence, JA = Journal of Adolescence, JYD = Journal of Youth Development, JAR = Journal of Adolescent Research, Y\&S = Youth \& Society, JYA = Journal of Youth and Adolescence.

Note2: The "Age" category does not add to $100 \%$ because manuscripts could be placed in multiple categories; the "sex" category does not add to $100 \%$ because approximately $8 \%$ of the manuscripts did not use youth in their sample frame, or because they did not specify the sex of their sample; the "Adults" category does not add up to 100 because not all manuscripts included adult perspectives. 


\section{Methodological Approaches}

Table 2 shows the breakdown of methodological approaches covered in the manuscripts reviewed for this analysis. The vast majority (93\%) of manuscripts published were empirical in nature. For the purposes of this study, manuscripts were categorized as empirical if they consisted of "original research where data collection or secondary analysis of data took place" (Graham \& Ismail, 2011, p. 127). Roughly 7\% of the manuscripts published were non-empirical, and could generally be described as literature reviews, methodology discussions, or comments on theory. The Journal of Youth Development appeared more likely than the other major journals to publish manuscripts of this type.

Most of the articles published (63\%) used traditional quantitative data collection and analysis techniques, including cross-sectional surveys, experimental or quasi-experimental design, or secondary data analysis. Of those reviewed, the Journal of Adolescence was the most likely to publish quantitative papers, although quantitative techniques were generally the methodology of choice for a majority of the manuscripts reviewed. Approximately one-third (30\%) of manuscripts used qualitative or mixed methods. Qualitative methods included observation, interviews, focus groups, case studies, or historical/content analysis techniques, whereas multiple or mixed methods studies generally employed both quantitative and qualitative approaches to answer their research questions.

Table 2

Methodological Approach

\begin{tabular}{|l|c|c|}
\hline Methodological Approach & N & \% \\
\hline Quantitative Methods & 292 & 63 \\
\hline Qualitative Methods & 82 & 18 \\
\hline Multiple or Mixed Methods & 54 & 7 \\
\hline Non-Empirical & 34 & 100.0 \\
\hline Total & 363 & \\
\hline
\end{tabular}

Table 3 provides a closer examination of the methodologies employed, both in the aggregate and by journal. For example, cross-sectional surveys or questionnaires were the most frequently used methodology (42\%), followed by experimental or quasi-experimental designs (12\%). Studies that used experimental, pre-experimental or quasi-experimental designs were those that made an effort to compare intervention effects with a suitable control group, or those where subjects served as their own controls, such as studies using a pre-test/post-test methodology (Creswell, 2009). Secondary data analysis accounted for $10 \%$ of the manuscripts published on positive youth development in the journals reviewed. Youth \& Society appeared to have the largest percentage of studies utilizing secondary datasets.

The most frequently occurring qualitative technique was the use of interviews or focus groups $(13 \%)$, followed by case studies (3\%). The Journal of Youth Development was the most likely journal to publish case studies, reflecting its commitment to bridging research and practice. Other qualitative techniques (e.g. direct observation of behavior, historical and/or content 
analysis) were used in less than $2 \%$ of the published manuscripts related to positive youth development. Multiple or mixed methods approaches accounted for approximately $12 \%$ of the total number of manuscripts published on positive youth development in the past 10 years, although more than $25 \%$ of the manuscripts published in the Journal of Research on Adolescence utilized multiple or mixed methods. Tables 2 and 3 show the breakdown of methodological approaches by journal and in the aggregate.

Table 3

Specific Methodologies Employed

\begin{tabular}{|c|c|c|c|c|c|c|c|}
\hline & JRA & JA & JYD & JAR & Y\&S & JYA & Total \\
\hline Survey & $\begin{array}{c}9 \\
(35 \%)\end{array}$ & $\begin{array}{c}31 \\
(62 \%)\end{array}$ & $\begin{array}{c}38 \\
(22 \%)\end{array}$ & $\begin{array}{c}14 \\
(38 \%)\end{array}$ & $\begin{array}{c}27 \\
(37 \%)\end{array}$ & $\begin{array}{c}73 \\
(74 \%)\end{array}$ & $\begin{array}{c}192 \\
(42 \%)\end{array}$ \\
\hline $\begin{array}{l}\text { Experimental } \\
\text { Design }\end{array}$ & $\begin{array}{c}1 \\
(4 \%)\end{array}$ & $\begin{array}{c}9 \\
(18 \%)\end{array}$ & $\begin{array}{c}40 \\
(23 \%)\end{array}$ & $\begin{array}{c}2 \\
(5 \%)\end{array}$ & $\begin{array}{c}1 \\
(1 \%)\end{array}$ & $\begin{array}{c}1 \\
(1 \%)\end{array}$ & $\begin{array}{c}54 \\
(12 \%)\end{array}$ \\
\hline Direct Observation & $\begin{array}{c}0 \\
(0 \%)\end{array}$ & $\begin{array}{c}0 \\
(0 \%)\end{array}$ & $\begin{array}{c}4 \\
(2 \%)\end{array}$ & $\begin{array}{c}1 \\
(3 \%)\end{array}$ & $\begin{array}{c}0 \\
(0 \%)\end{array}$ & $\begin{array}{c}0 \\
(0 \%)\end{array}$ & $\begin{array}{c}5 \\
(1 \%)\end{array}$ \\
\hline $\begin{array}{l}\text { Interviews/Focus } \\
\text { Groups }\end{array}$ & $\begin{array}{c}4 \\
(15 \%)\end{array}$ & $\begin{array}{c}3 \\
(6 \%)\end{array}$ & $\begin{array}{c}26 \\
(15 \%)\end{array}$ & $\begin{array}{c}12 \\
(33 \%)\end{array}$ & $\begin{array}{c}9 \\
(12 \%)\end{array}$ & $\begin{array}{c}6 \\
(6 \%)\end{array}$ & $\begin{array}{c}60 \\
(13 \%)\end{array}$ \\
\hline Case Studies & $\begin{array}{c}0 \\
(0 \%)\end{array}$ & $\begin{array}{c}0 \\
(0 \%)\end{array}$ & $\begin{array}{c}14 \\
(8 \%)\end{array}$ & $\begin{array}{c}1 \\
(3 \%)\end{array}$ & $\begin{array}{c}1 \\
(1 \%)\end{array}$ & $\begin{array}{c}0 \\
(0 \%)\end{array}$ & $\begin{array}{c}16 \\
(3 \%)\end{array}$ \\
\hline $\begin{array}{l}\text { Historical/Content } \\
\text { Analysis }\end{array}$ & $\begin{array}{c}0 \\
(0 \%)\end{array}$ & $\begin{array}{c}0 \\
(0 \%)\end{array}$ & $\begin{array}{c}0 \\
(0 \%)\end{array}$ & $\begin{array}{c}0 \\
(0 \%)\end{array}$ & $\begin{array}{c}1 \\
(1 \%)\end{array}$ & $\begin{array}{c}0 \\
(0 \%)\end{array}$ & $\begin{array}{c}1 \\
(0 \%)\end{array}$ \\
\hline $\begin{array}{l}\text { Multiple or Mixed } \\
\text { Methods }\end{array}$ & $\begin{array}{c}7 \\
(27 \%)\end{array}$ & $\begin{array}{c}5 \\
(10 \%)\end{array}$ & $\begin{array}{c}18 \\
(10 \%)\end{array}$ & $\begin{array}{c}6 \\
(16 \%)\end{array}$ & $\begin{array}{c}13 \\
(18 \%)\end{array}$ & $\begin{array}{c}5 \\
(5 \%)\end{array}$ & $\begin{array}{c}54 \\
(12 \%)\end{array}$ \\
\hline $\begin{array}{l}\text { Secondary Data } \\
\text { Analysis }\end{array}$ & $\begin{array}{c}4 \\
(15 \%)\end{array}$ & $\begin{array}{c}0 \\
(0 \%)\end{array}$ & $\begin{array}{c}9 \\
(5 \%)\end{array}$ & $\begin{array}{c}1 \\
(3 \%)\end{array}$ & $\begin{array}{c}18 \\
(25 \%)\end{array}$ & $\begin{array}{c}14 \\
(14 \%)\end{array}$ & $\begin{array}{c}46 \\
(10)\end{array}$ \\
\hline $\begin{array}{l}\text { Literature Review, } \\
\text { Theory Paper or } \\
\text { Methodology } \\
\text { Discussion }\end{array}$ & $\begin{array}{c}1 \\
(5 \%)\end{array}$ & $\begin{array}{c}2 \\
(4 \%)\end{array}$ & $\begin{array}{c}28 \\
(16 \%)\end{array}$ & $\begin{array}{c}0 \\
(0 \%)\end{array}$ & $\begin{array}{c}3 \\
(4 \%)\end{array}$ & $\begin{array}{c}0 \\
(0 \%)\end{array}$ & $\begin{array}{c}34 \\
(7 \%)\end{array}$ \\
\hline Total & $\begin{array}{c}26 \\
(100 \%)\end{array}$ & $\begin{array}{c}50 \\
(100 \%)\end{array}$ & $\begin{array}{c}177 \\
(100 \%)\end{array}$ & $\begin{array}{c}37 \\
(100 \%)\end{array}$ & $\begin{array}{c}73 \\
(100 \%)\end{array}$ & $\begin{array}{c}99 \\
(100 \%)\end{array}$ & $\begin{array}{c}462 \\
(100 \%)\end{array}$ \\
\hline
\end{tabular}

Note: JRA = Journal of Research on Adolescence, JA = Journal of Adolescence, JYD = Journal of Youth Development, JAR = Journal of Adolescent Research, Y\&S = Youth \& Society, JYA = Journal of Youth and Adolescence

\section{Research Settings}

Table 4 provides a breakdown of the settings and contexts for youth development research. In addition to population characteristics and methodology, manuscripts were categorized based on the settings or contexts where research related to youth took place. Most studies took place in school (43\%) or community-based organizational settings (21\%). Studies of youth within the school context were dominant in all of the major research journals in the field. The Journal of Youth Development was more likely than the other journals to publish studies that took place within community-based organizational settings. Interestingly, fewer than 1 in 10 studies used the home/family as a research setting $(8 \%)$, although more than one-third (39\%) of the 
manuscripts published in the Journal of Research on Adolescence had this focus. Research that took place within the neighborhood/community context was also underrepresented, with only $7 \%$ of manuscripts focusing on this ecology. Perhaps most surprisingly, none of the research manuscripts covered were identified as having taken place exclusively in faith-based settings or organizations.

A number of studies (21\%) reported focusing on youth in multiple contexts. For example, the physical site of the research may have taken place within an afterschool program, yet the research questions themselves focused on academic achievement (school), family life (home/family) and involvement in structured activities outside of school (community-based organizations). As such, these studies did not focus on a specific youth development setting, but attempted to answer questions related to a range of ecological contexts. Notably, more than one-quarter of the manuscripts in Youth \& Society and the Journal of Youth and Adolescence focused on youth in multiple ecological contexts.

Table 4

Research Settings

\begin{tabular}{|c|c|c|c|c|c|c|c|}
\hline & JRA & JA & JYD & JAR & Y\&S & JYA & Total \\
\hline Home/Family & $\begin{array}{c}10 \\
(39 \%)\end{array}$ & $\begin{array}{c}9 \\
(18 \%)\end{array}$ & $\begin{array}{c}5 \\
(3 \%)\end{array}$ & $\begin{array}{c}2 \\
(5 \%)\end{array}$ & $\begin{array}{c}6 \\
(8 \%)\end{array}$ & $\begin{array}{c}5 \\
(5 \%)\end{array}$ & $\begin{array}{c}37 \\
(8 \%)\end{array}$ \\
\hline School & $\begin{array}{c}13 \\
(50 \%)\end{array}$ & $\begin{array}{c}32 \\
(64 \%)\end{array}$ & $\begin{array}{c}44 \\
(25 \%)\end{array}$ & $\begin{array}{c}18 \\
(49 \%)\end{array}$ & $\begin{array}{c}32 \\
(44 \%)\end{array}$ & $\begin{array}{c}59 \\
(60 \%)\end{array}$ & $\begin{array}{c}198 \\
(43 \%)\end{array}$ \\
\hline $\begin{array}{l}\text { Community-based } \\
\text { organization }\end{array}$ & $\begin{array}{c}0 \\
0 \\
(0)\end{array}$ & $\begin{array}{c}3 \\
(6 \%)\end{array}$ & $\begin{array}{c}80 \\
(45 \%)\end{array}$ & $\begin{array}{c}4 \\
(11 \%)\end{array}$ & $\begin{array}{c}4 \\
(6 \%)\end{array}$ & $\begin{array}{c}5 \\
(5 \%)\end{array}$ & $\begin{array}{c}96 \\
(21 \%)\end{array}$ \\
\hline Neighborhood/community & $\begin{array}{c}3 \\
(12 \%)\end{array}$ & $\begin{array}{c}3 \\
(6 \%)\end{array}$ & $\begin{array}{c}13 \\
(7 \%)\end{array}$ & $\begin{array}{c}4 \\
(11 \%)\end{array}$ & $\begin{array}{c}10 \\
(14 \%)\end{array}$ & $\begin{array}{c}1 \\
(1 \%)\end{array}$ & $\begin{array}{c}34 \\
(7 \%)\end{array}$ \\
\hline Faith-based organization & $\begin{array}{c}0 \\
(0 \%)\end{array}$ & $\begin{array}{c}0 \\
(0 \%)\end{array}$ & $\begin{array}{c}0 \\
(0 \%)\end{array}$ & $\begin{array}{c}0 \\
(0 \%)\end{array}$ & $\begin{array}{c}0 \\
(0 \%)\end{array}$ & $\begin{array}{c}0 \\
(0 \%)\end{array}$ & $\begin{array}{c}0 \\
(0 \%)\end{array}$ \\
\hline Non-specific/Multiple & $\begin{array}{c}0 \\
(0 \%)\end{array}$ & $\begin{array}{c}3 \\
(6 \%)\end{array}$ & $\begin{array}{c}35 \\
(20 \%)\end{array}$ & $\begin{array}{c}9 \\
(24 \%)\end{array}$ & $\begin{array}{c}21 \\
(29 \%)\end{array}$ & $\begin{array}{c}29 \\
(29 \%)\end{array}$ & $\begin{array}{c}97 \\
(21 \%)\end{array}$ \\
\hline Total & $\begin{array}{c}26 \\
(100 \%)\end{array}$ & $\begin{array}{c}50 \\
(100 \%)\end{array}$ & $\begin{array}{c}177 \\
(100 \%)\end{array}$ & $\begin{array}{c}37 \\
(100 \%)\end{array}$ & $\begin{array}{c}73 \\
(100 \%)\end{array}$ & $\begin{array}{c}99 \\
(100 \%)\end{array}$ & $\begin{array}{c}462 \\
(100 \%)\end{array}$ \\
\hline
\end{tabular}

Note: JRA = Journal of Research on Adolescence, $\mathrm{JA}=$ Journal of Adolescence, JYD = Journal of Youth Development, JAR = Journal of Adolescent Research, Y\&S = Youth \& Society, JYA = Journal of Youth and Adolescence

\section{Topical Areas}

A key component of this integrative review was the categorization of articles based on key themes or topic areas. This allowed us to identify the major thrusts and topical gaps in the research related to positive youth development in the manuscripts that we reviewed over the past 10 years. We used non-exclusive coding so that manuscripts might be placed in multiple categories to adequately capture the intent of the authors, and as a recognition that many of these topical areas overlapped and were addressed within the same study. The 12 main topical areas that emerged from the keyword analysis, along with the numbers and percentages of manuscripts categorized in each area, are listed in Table 5, and described below: 
Table 5

Topical Areas

\begin{tabular}{|l|c|c|c|c|c|c|c|}
\hline & JRA & JA & JYD & JAR & Y\&S & JYA & Total \\
\hline Professional & 0 & 0 & 24 & 0 & 1 & 0 & 25 \\
Development & $(0 \%)$ & $(0 \%)$ & $(14 \%)$ & $(0 \%)$ & $(1 \%)$ & $(0 \%)$ & $(5 \%)$ \\
\hline Youth Activities & 7 & 6 & 74 & 13 & 29 & 28 & 157 \\
$(27 \%)$ & $(12 \%)$ & $(42 \%)$ & $(35 \%)$ & $(4 \%)$ & $(28 \%)$ & $(34 \%)$ \\
\hline YD Processes and & 20 & 32 & 123 & 15 & 53 & 32 & 275 \\
Outcomes & $(87 \%)$ & $(64 \%)$ & $(70 \%)$ & $(41 \%)$ & $(73 \%)$ & $(32 \%)$ & $(60 \%)$ \\
\hline Academic & 12 & 11 & 33 & 15 & 16 & 26 & 113 \\
Performance & $(46 \%)$ & $(22 \%)$ & $(19 \%)$ & $(41 \%)$ & $(22 \%)$ & $(26 \%)$ & $(24 \%)$ \\
\hline PYD Influence on & 11 & 23 & 21 & 3 & 1 & 19 & 78 \\
Risk Behavior & $(42 \%)$ & $(46 \%)$ & $(12 \%)$ & $(8 \%)$ & $(1 \%)$ & $(19 \%)$ & $(17 \%)$ \\
\hline Youth Engagement & 16 & 8 & 79 & 9 & 13 & 9 & 134 \\
& $(62 \%)$ & $(16 \%)$ & $(45 \%)$ & $(24 \%)$ & $(18 \%)$ & $(9 \%)$ & $(29 \%)$ \\
\hline Resilience & 3 & 5 & 8 & 18 & 3 & 4 & 41 \\
\hline Asset- and Capacity- & $18 \%)$ & $(10 \%)$ & $(5 \%)$ & $(49 \%)$ & $(4 \%)$ & $(4 \%)$ & $(9 \%)$ \\
Building & $(69 \%)$ & $(52 \%)$ & $(40 \%)$ & $(5 \%)$ & $(3 \%)$ & $(41 \%)$ & $(35 \%)$ \\
\hline Health and Wellness & $(12 \%)$ & $(12 \%)$ & $(7 \%)$ & $(8 \%)$ & 15 & 26 & 64 \\
\hline Peer Relationships & $(12 \%)$ & $(24 \%)$ & $(4 \%)$ & $(24 \%)$ & $(16 \%)$ & $(26 \%)$ & $(14 \%)$ \\
\hline Family & 13 & 21 & 15 & 16 & 21 & 38 & 124 \\
\hline Youth/Adult & $(50 \%)$ & $(42 \%)$ & $(9 \%)$ & $(43 \%)$ & $(29 \%)$ & $(38 \%)$ & $(27 \%)$ \\
Relationships & 4 & 4 & 15 & 6 & 8 & 10 & 47 \\
$(15 \%)$ & $(8 \%)$ & $(9 \%)$ & $(16 \%)$ & $(11 \%)$ & $(10 \%)$ & $(10 \%)$ \\
\hline
\end{tabular}

Note: JRA = Journal of Research on Adolescence, JA = Journal of Adolescence, JYD = Journal of Youth Development, JAR = Journal of Adolescent Research, Y\&S = Youth \& Society, JYA = Journal of Youth and Adolescence

Note ${ }^{2}$ : The column denominator is the total number of articles included in the review by journal; the denominator for the "Total" column is the sum of all of the included articles ( $N=462)$

1. Professional Development. This topical area included manuscripts focusing on the needs and issues related to youth development staff, program leaders, and volunteers. Studies in this category tended to focus on issues related to professionalism, staff training, professional education, and worker competencies. Only $5 \%$ of the manuscripts covered in this review fit into this category. The Journal of Youth Development was the most likely to publish manuscripts related to professional development in the youth development field.

2. Youth Activities. Manuscripts that were placed in this topical area included those that focused on structured, intentional learning activities. This included manuscripts that focused on youth development programs such as sports, camps, outdoor recreation, arts 
and drama, music, and after-school programs. Approximately one-third (34\%) of manuscripts addressed specific youth development programs or activities. Again, the Journal of Youth Development was the most likely journal to publish manuscripts in this category.

3. Youth Development Processes and Outcomes. This topical area included manuscripts focusing on assessing program effectiveness, identifying the benefits or outcomes that accrue from participation in youth development programs, or examining how participation affects different groups of youth (e.g. age, gender, race/ethnicity). Manuscripts were also placed into this category that addressed the scalability of youth development programs, or studies that focused on activity participation as a program outcome. Almost two-thirds (60\%) of the studies reviewed here were placed in this category. Many of these articles focused on the socio-demographics of program or activity participation, particularly regarding how program participation or outcomes differed based on the background of the youth involved.

4. Academic Engagement. This topical area included manuscripts related to academic performance, such as grades or test scores, and other areas of academic participation, such as school attendance. Manuscripts that focused on school connectedness or the school learning environment were also placed in this category. Almost one-fourth (24\%) of the manuscripts reviewed were categorized in this area.

5. Positive Youth Development Influence on Risk Behavior. This topical area included manuscripts that addressed issues of risk behavior reduction as a result of positive youth development programs and strategies. Studies that addressed various forms of risk behavior, such as problem drinking, sexual behavior, violence, bullying or other forms of risk behavior were included in this analysis if the focus of the study related to the influence of positive youth development programs or contexts on mitigating these problems. Less than one-fifth (17\%) of the manuscripts were categorized in this area. The Journal of Research on Adolescence and the Journal of Adolescence appeared more likely to publish articles that focused on the influence of positive youth development on risk behavior reduction.

6. Youth Engagement. Manuscripts were placed into this category if they dealt with the broad issue of youth participation and engagement. This included studies that focused on youth involvement in the community, participation in service learning activities, youth leadership roles, and youth voice. Less than one-third (29\%) of the manuscripts reviewed focused on youth participation and engagement. Approximately $62 \%$ of the studies that were reviewed in the Journal of Research on Adolescence addressed this topical area.

7. Resilience. This topical area included studies that focused on positive youth development and youth thriving, particularly for young people living in high-risk environments. This included studies that addressed coping strategies, positive adjustment, and protective factors. Only $9 \%$ of the studies that were reviewed focused on issues related to resilience, although $49 \%$ of the papers reviewed in the Journal of Adolescent Research addressed some aspect of resilience.

8. Asset- and Capacity-Building. Manuscripts placed in this topical area included those that addressed the skills and competencies of youth. This included studies that incorporated models such as the 40 Developmental Assets, the Five C's, or that focused on skills such as initiative, goal setting, effort, pro-social behavior, team functioning, and problem solving. More than one-third of the studies reviewed (35\%) were placed in this category. 
9. Family. This topical area included manuscripts focusing on family dynamics as they contribute to positive youth development. Manuscripts that were placed in this area included those that focused on family support, family rituals, parent involvement, sibling relationships, and family communication. Surprisingly, only $27 \%$ of the manuscripts reviewed addressed issues related to the family, although exactly half of the studies reviewed in the Journal of Research on Adolescence had this focus. At the other end of the spectrum, only $9 \%$ of the studies in the Journal of Youth Development appeared to have a focus on the family.

10. Health and Wellness. Manuscripts that were placed in this category were those that had a specific focus on physical health. This included papers that focused on physical activity promotion, maintaining or achieving a healthy weight, and healthy eating and nutrition. Despite the increasing attention given to adolescent health and physical activity, only $14 \%$ of the studies reviewed addressed health and wellness issues.

11. Peer Relationships. This topical area included studies that addressed issues related to peer support, friendships, peer-to-peer mentoring or other forms of positive peer relationships. Approximately $14 \%$ of the studies reviewed focused on peer relationships, with the highest percentage of studies in this area appearing in the Journal of Adolescence and the Journal of Adolescent Research.

12. Youth-Adult Relationships. Manuscripts placed in this category focused on the positive roles of non-parental adults in the lives of youth, including mentoring relationships, nonparental adult support, and role modeling. Despite the importance of non-parental adult role models and mentoring in the lives of youth, only $10 \%$ of the articles published addressed this topic directly. It appeared that most of the published studies in this area focused on formal mentoring programs.

13.

\section{Discussion and Recommendations}

Integrative reviews provide a big-picture snapshot of the research literature and can help provide an understanding of the strengths and gaps in the body of knowledge of a particular field. This integrative review focused on the positive youth development research published between 2001-2010 in five top-tier youth journals (Journal of Research on Adolescence, Journal of Adolescence, Journal of Adolescent Research, Youth \& Society, and the Journal of Youth and Adolescence), as well as one research-to-practice journal (Journal of Youth Development). The findings and discussion related to the research on positive youth development provided in this paper should be taken within the scope of this analysis. However, several observations can be made with respect to the research covered in this effort.

First, the vast majority of research published in the major, top-tier youth journals did not fit into the category of positive youth development research. Generally speaking, manuscripts published about youth in the major research journals do not utilize a strengths-based approach or provide an examination of the processes that foster positive youth well-being. These approaches and processes come in the form of supports, opportunities, programs, and services that intentionally leverage positive youth outcomes. This finding mirrors research conducted in the field of positive psychology, where Myers (2000) found that the vast majority of articles published since 1967 focused on negative emotions vs. positive emotions. This may be reflective of the larger context in which research related to youth takes place. For example, it is likely that funded research studies of the type that would most likely appear in top-tier research journals still reflect a bias towards a problem- or deficit-based view of young people. While several of the major research journals that were reviewed for this effort published one or more 
special issues devoted to positive youth development or positive psychology (e.g. Journal of Research on Adolescence, Journal of Youth and Adolescence), the major thrust of the papers in the regular issues was not reflective of a positive youth development perspective.

Second, the key transition stages from late childhood to adolescence, and from adolescence to adulthood appear understudied in the positive youth development literature. Much of the published research on positive youth development was focused on what could be considered to be the traditional definition of adolescence (roughly ages 13-18). While this makes sense, it is generally understood that the terms youth and adolescence focus on the second decade of life - roughly ages 10 to 20 . Others have noted that the upper boundary of adolescence is now extending into the early to mid 20s (Larson, 2002). These more expansive definitions of youth are not widely reflected in the positive youth development research covered for this paper, given that roughly 1 in 5 published studies focused on youth between the ages 10-12 and between the ages of $19-21$. Only $5 \%$ of published studies were found covering the ages of 2225.

Third, the clear majority of the research that was reviewed involved both boys and girls. This is perhaps reflective of a positive youth development philosophy that addresses the strengths and abilities of all youth, rather than focusing on deficits or differences between groups of youth. It was interesting to note that while a small number of studies (5\%) were exclusively focused on girls, we identified only one study that focused exclusively on boys from a positive youth development perspective.

Fourth, less than $10 \%$ of manuscripts included the perspectives of parents and the key adults who have an influence on youth. While it stands to reason that youth development research would focus primarily on young people themselves, it was curious that so few of the studies involved adults in the research design, or asked questions directly pertaining to the roles of parental and non-parental adults. In fact, only $8 \%$ of the total studies reviewed focused exclusively on adults. Given the tremendous influence that key adults have on positive youth development, more research focusing on this population needs to be undertaken.

Fifth, studies of youth that focus on critical developmental ecologies, such as the home and family, or studies that addressed youth in the context of their neighborhoods or larger communities, were underrepresented in this review. Of the studies reviewed in this analysis, the largest percentage examined positive youth development within the context of school or afterschool settings, followed by studies that were situated within or involved youth in communitybased organizations. This is perhaps understandable, particularly given the amount of time that youth spend in school and in structured programs and activities outside of school. However, given that positive youth development is influenced by the interplay of multiple ecologies, more research on the home, family, and neighborhood contexts and how they impact youth is needed.

Sixth, a majority of the studies used a quantitative approach in answering the research questions posed. Cross-sectional surveys-either in the form of paper/pencil or web-based questionnaires-were the most popular data collection tool. A relatively small number of studies engaged in secondary data analysis, such as those that answered questions using the National Longitudinal Study of Adolescent Health (Add Health) (Dodge \& Lambert, 2009) or the 4-H Study on Positive Youth Development (Theokas, Lerner, Phelps, \& Lerner, 2006). In addition, less than $15 \%$ of the published studies attempted to use some level of experimental design. While the difficulties of conducting experimental research in the social sciences are well noted, 
the relatively small number of studies that were classified in this category is potentially concerning, particularly with respect to the methodological rigor of the positive youth development research. Curiously, the Journal of Youth Development had approximately 23\% of its manuscripts categorized as pre-experimental, quasi-experimental, or experimental. This may be reflective of the number of program evaluation studies that are published in the Journal of Youth Development. It should be noted that even though a study was classified as using an experimental design (or any other methodology for that matter), the quality of the research and the actual rigor of the study was beyond the scope of this review.

Qualitative studies and studies that used multiple or mixed methods accounted for less than one third of the published manuscripts in this review. While rigorous quantitative studies can provide data that allow researchers to measure program impact, compare groups, and generalize results, qualitative techniques, such as the use of grounded theory or ethnographic approaches, allow researchers to ask deeper questions that address the nature and meaning of positive youth development within the lived experiences of youth. Rigorous, research-based case studies of successful youth programs, settings or contexts can provide useful bestpractices models that could possibly be replicated elsewhere. Finally, complex questions related to program effectiveness, resiliency, or community efficacy may be best answered by employing multiple methodological approaches. Positive youth development researchers should consider employing more diverse methodologies in answering the kinds of complex research questions that are most interesting to the field.

This review identified 12 main topical areas that best captured the breadth of positive youth development research. These 12 non-exclusive topical areas (i.e. studies could, and often did, encompass more than one topic) included professional development, youth activities, youth development processes and outcomes, academic engagement, positive youth development influence on risk behavior, youth engagement, resilience, asset- and capacity-building, family, health and wellness, peer relationships, and youth-adult relationships. It makes sense given the applied nature of the youth development profession that most published studies would reflect the field's focus on structured programs and activities. This was the case for the studies included in this review. A majority focused on the effectiveness of specific program interventions or the outcomes associated with participation in various program types (e.g. sports, camp, afterschool, outdoor, 4-H) for different kinds of youth. This review also uncovered several notable gaps, which are discussed below.

First, only $14 \%$ of the studies focused on issues related to health and wellness. This is surprising, given the recent attention on increasing rates of obesity, poor nutrition, and lack of physical activity among many youth. It is likely that a majority of the research concerning adolescent health is being published elsewhere. Publication outlets such as the Journal of School Health, Journal of Physical Activity and Health, and Journal of Adolescent Health are likely places for research of this nature to be published. However, the connection between adolescent health and positive youth development approaches appears to have significant research potential, yet it has received scant attention in the major, top-tier research journals in the field.

Second, positive youth development and its relationship to the reduction of risk behavior accounted for less than one-fifth of the studies reviewed here. Similarly, research that specifically addressed resiliency skills (e.g. coping, adjustment) encompassed just one tenth of the studies in this analysis. As we found in undertaking this review, the majority of research on youth tends to focus on a deficits- or problems-based perspective. However, exposure to 
positive youth development settings has been shown to have an inverse relationship with adolescent problem behavior (Scales \& Leffert, 2004). It has been noted that research funding tends to follow studies that focus on vulnerable populations or that focus on risk behavior reduction. To that end, it stands to reason that more studies addressing the link between positive youth development programs, settings, and contexts and reducing youth risk behavior would be especially worthy of funding and support.

Third, studies focusing on topics related to the family, and studies that addressed positive peer influences, were not as frequently categorized in this review. Studies involving family perspectives were not as prevalent in the Journal of Youth Development in particular. This journal tends to have an applied focus, particularly with respect to bridging the gap between research and practice (with an emphasis on the youth development practitioner). However, research studies addressing the interaction between family life and positive youth development have immense practical implications for youth development organizations and professionals. Similarly, studies focusing on positive peer influences were noted in roughly $10 \%$ of the papers reviewed here. Given the enormous influence of peers and family on adolescent attitudes and behavior, it is safe to suggest that additional research addressing these areas from a positive youth development perspective is needed.

Fourth, the lack of studies that focused on the influence of non-parental adult relationships for youth was of particular concern. Most of the studies that addressed adult-youth relationships did so from the parent-child perspective, and most of these were not included in this review because they dealt with parent influences on negative or problematic outcomes or behaviors. Only $10 \%$ of the studies included in this review focused on the role that non-parental adults play in the lives of youth. Of these, most focused on formal mentoring programs, yet only a relative few addressed the natural mentoring roles that athletic coaches, neighbors, religious leaders, 4-H educators, or other non-parental adults play that have the potential to influence positive well-being.

Finally, only $5 \%$ of the papers reviewed dealt with professional development issues related to youth development workers, organizational leaders, or volunteers. It is quite possible that the bulk of the research focused on professional development for the youth development professional is published outside of the journals covered for this review. However, even the Journal of Youth Development which is more likely than the others to focus on professional development issues, published less than $14 \%$ of its papers on this topic. As the field of youth development grows, the professional identity of youth development workers is becoming more salient. More research addressing issues related to the unique professional development needs of youth workers, such as focusing on job competencies, training and education models, job motivation, burnout, and organizational commitment, among others, is needed.

\section{Conclusion}

Attempting to systematically describe the themes and trends in positive youth development research is an enormous undertaking, particularly given the various and diverse publication outlets that are available for this type of research. This integrative review is a first attempt at trying to understand what the youth development research literature looks like, with a particular focus on studies that have been published in five top-tier journals plus one applied research journal over the last ten years. As this review found, positive youth development studies constitute a relatively small portion of the overall research base dealing with youth and adolescence. As the field matures, continuous and ongoing investigation of the methods, 
questions, rigor, and key findings related to positive youth development research will undoubtedly help the body of knowledge deepen and grow.

\section{References}

Benson, P.L., Scales, P.C., Hamilton, S.F., \& Sesma, A. (2006). Positive youth development: Theory, research and applications. In R.M. Learner (Ed.). Theoretical models of human development. Volume 1 of the Handbook of Child Psychology ( $6^{\text {th }}$ Edition) (pp. 894-941). Hoboken, NJ: Wiley.

Benzies, K., \& Mychasiuk, R. (2009). Fostering family resiliency: A review of the key protective factors. Child and Family Social Work, 14(1), 103-114.

Bocarro, J.N., Greenwood, P.B., \& Henderson, K.A. (2008). An integrative review of youth development research in selected United States recreation journals. Journal of Park and Recreation Administration, 26(2), 4-27.

Bogenschneider, K., \& Corbett, T.J. (2010). Family policy: Becoming a field of inquiry and subfield of social policy. Journal of Marriage and Family, 72(3), 783-803.

Chambers, R., Gullone, E., \& Allen, N. (2009). Mindful emotional regulation: An integrative review. Clinical Psychology Review, 29(6), 560-572.

Chesla, C.A., \& Rungreangkulkij, S. (2001). Nursing research on family processes in chronic illness in ethnically diverse families: A decade review. Journal of Family Nursing, 73 ), 230-243.

Costello, J., Toles, M., Spielberger, J., \& Wynn, J. (2001). How history, ideology, and structure shape the organizations that shape youth. In P.L. Benson \& K.J. Pittman (Eds.). Trends in youth development: Visions, realities, and challenges (pp. 191-229). Boston, MA: Kluwer Academic Publishers.

Creswell, J.W. (2009). Research design: Qualitative, quantitative, and mixed methods approaches ( $3^{\text {rd }}$ Edition). Thousand Oaks, CA: Sage Publications.

Dodge, T., \& Lambert, S.F. (2009). Positive self-beliefs as a mediator of the relationship between adolescents' sports participation and health in young adulthood. Journal of Youth and Adolescence, 38, 813-825.

D'Onofrio, B.M., \& Lahey, B.B. (2010). Biosocial influences on the family: A decade review. Journal of Marriage \& Family, 72(3), 762-782.

Eccles, J., \& Gootman, J.A. (2002). Community programs to promote youth development. Washington, DC: National Academies Press.

Graham, T.M., \& Ismail, T. (2011). Content and methods in the Journal of Community Psychology between 2003 and 2007. Journal of Community Psychology, 39(2), 121-135. 
Guiberson, M. (2009). Hispanic representation in special education: Patterns and implications. Preventing School Failure, 53(3), 167-176.

Hall, G.S. (1904). Adolescence: Its psychology and its relations to psychology, anthropology, sociology, ex, crime, religion, and education. New York, NY: Appleton.

Hamilton, S.F., Hamilton, M.A., \& Pittman, K.J. (2004). Principles for youth development. In S.F. Hamilton \& M.A. Hamilton (Eds.). The youth development handbook: Coming of age in American communities. Thousand Oaks, CA: Sage Publications.

Jackson, G.B. (1980). Methods for integrative reviews. Review of Educational Research, 50, 438-460.

Kingery, J.N., Erdley, C.A., Marshall, K.C., Whitaker, K.G., \& Reuter, T.R. (2010). Peer experiences of anxious and socially withdrawn youth: An integrative review of the developmental and clinical literature. Clinical Child and Family Psychology Review, 13(1), 91128.

Kosutic, I., \& McDowell, T. (2008). Diversity and social justice issues in the family teherapy literature: A decade review. Journal of Feminist Family Therapy, 20(2), 142-165.

Larson, R.W. (2000). Toward a psychology of positive youth development. American Psychologist, 55(1), 170-183.

Larson, R.W. (2002, November-December). The future of adolescence: Lengthening ladders to adulthood. The Futurist, 16-20.

Lerner, R.M. (2005, September). Promoting positive youth development: Theoretical and empirical bases. White paper prepared for the Workshop on the Science of Adolescent Health and Development, National Research Council/Institute of Medicine. Washington, DC: National Academies of Science.

McCullick, B., Schempp, P., Mason, I., Foo, C., Vickers, B., \& Connolly, G. (2009). A scrutiny of the coaching education program scholarship since 1995. Quest, 61(3), 322-335.

Myers, D. (2000). Hope and happiness. In J.E. Gillham (Ed.). The science of optimism and hope (pp. 323-336). Philadelphia, PA: Templeton Foundation Press.

Pittman, K.J., \& Wright, M. (1991). Bridging the gap: A rationale for enhancing the role of community organizations in promoting youth development. Washington, DC: Academy for Educational Development, Center for Youth Development and Policy Research.

Pittman, K., Irby, M., \& Ferber, T. (2001). Unfinished business: Further reflections on a decade of promoting youth development. In P.L. Benson \& K.J. Pittman (Eds.). Trends in youth development: Visions, realities, and challenges (pp. 3-50). Boston, MA: Kluwer Academic Publishers.

Roth, J.L., \& Brooks-Gunn, J. (2003). What exactly is a youth development program? Answers from research and practice. Applied Developmental Science, 72 , 94-111. 
Roth, J., Brooks-Gunn, J., Murray, L., \& Foster, W. (1998). Promoting healthy adolescents: Synthesis of youth development program evaluations. Journal of Research on Adolescence, 8(4), 423-459. DOI: 10.1207/s15327795jra0804_2.

Russell, S.T., Card, N.A., \& SusmanE.J. (2011). Introduction: A decade review of research on adolescence. Journal of Research on Adolescence, 21(1), 1-2.

Scales, P.C., \& Leffert, N. (2004). Developmental assets: A synthesis of the scientific research on adolescent development ( $2^{\text {nd }} E d$.). Minneapolis, MN: Search Institute.

Steingraber, S. (2007). The falling age of puberty in U.S. Girls: What we know, what we need to know. San Francisco, CA: The Breast Cancer Fund.

Stodolska, M. (2008). Adaptation processes among young immigrants: An integrative review. Journal of Immigrant and Refugee Studies, 6(3), 34-59.

Telzer, E.H. (2011). Expanding the acculturation gap-distress model: An integrative review of the research. Human Development, 53(6), 313-340.

Theokas, C., Lerner, J., Phelps, E. \& Lerner, R. (2006). Cacophony and change in youth after school activities: Findings from the 4-H study of positive youth development. Journal of Youth Development, 1(1).

(C) Copyright of Journal of Youth Development $~$ Bridging Research and Practice. Content may not be copied or emailed to multiple sites or posted to a listserv without copyright holder's express written permission. However, users may print, download or email articles for individual use. 